\title{
Dose Remittances Matter for Openness and Financial Stability: Evidence From Least Developed Economies
}

\author{
Meng Miao ${ }^{1}$ and Md. Qamruzzaman ${ }^{2 *}$ \\ ${ }^{1}$ Renmin University of China, Hanqing Advanced Institute of Economics and Finance, Beijing, China, ${ }^{2}$ School of Business \\ and Economics, United International University, Dhaka, Bangladesh
}

OPEN ACCESS

Edited by:

Mark Anthony Camilleri,

University of Malta, Malta

Reviewed by:

Festus Victor Bekun,

Gelișim Üniversitesi, Turkey

loannis Kostakis,

Harokopio University, Greece

*Correspondence:

Md. Qamruzzaman

zaman_wut16@yahoo.com; qamruzzaman@bus.uiu.ac.bd

Specialty section:

This article was submitted to

Organizational Psychology,

a section of the journal

Frontiers in Psychology

Received: 17 April 2021

Accepted: 07 June 2021

Published: 10 August 2021

Citation:

Miao M and Qamruzzaman M (2021)

Dose Remittances Matter for

Openness and Financial Stability:

Evidence From Least Developed

Economies.

Front. Psychol. 12:696600

doi: $10.3389 /$ fpsyg.2021.696600
The study's motivation is to gauge the effects of remittances on openness: financial and economic openness and financial stability in least developed countries (LDCs) for the period spanning 1975-2018. The study applies Generalized Moment of Methods (GMM) and System-GMM to detect the magnitude of remittances, gross capital formation, and government debt on openness and financial stability, and their directional association is established by performing a Granger causality test with System-GMM specification. The results of cross-sectional dependency ascertain the presence of a common dynamic among the research units; on the other hand, both first, and second-generation unit root tests establish that variables are integrated either at level or after the first difference, neither variables are exposed to order of integration after second difference. A panel co-integration test based on error correction confirms the availability of the long-run association among variables. Study findings with GMM and System-GMM estimation expose positive statistically significant effects of remittance inflows to economic and financial openness and financial stability. In LDCs, remittance inflows positively augment economic and financial openness; moreover, financial stability remittances play a critical role. The study implemented the Granger causality test with System-GMM specification, and results disclosed the feedback hypothesis that is bidirectional causality availability in the tested empirical causal model.

JEL Classifications: F24, F43, P34.

Keywords: remittances, economic openness, financial openness, financial stability, system-GMM

\section{INTRODUCTION}

Remittances to developing countries go first and foremost to lower-middle-income and low-income countries. Lower-middle-income countries receive the most considerable amounts. However, remittances constitute a much higher share of total international flows to low-income countries (Gammeltoft, 2002). The position of immigrant remittances in economic growth is still a hot topic among academics and policymakers. Also, all countries are interested in international aid remittances; since they represent a large influx of financial capital; both industrialized and emerging economies are drawn to each other (Chami et al., 2005; Stojanov et al., 2019). Furthermore, if made more explicit, immigrant remittances can even help grow nations or be channeled into profitable 
investment in the economy (Straubhaar, 1986; Elbadawi and Rocha, 1992; Chami et al., 2003; Ratha, 2005).

In recent times, remittances have been considered the critical source in foreign capital flows in the economy, especially in developing nations, about $27 \%$ of GDP. The steady growth of remittances helps accelerate domestic capital and allows a higher degree of technological advancement, which eventually reduces transaction costs (Bevan et al., 2004; Aggarwal et al., 2011; Sibindi and Bimha, 2014). Furthermore, Nyamongo et al. (2012) advocated that remittances are a significant source of savings and money for wellness, schooling, and development, resulting in increased production and jobs leading to economic development. Aggarwal et al. (2011) postulated that financial sector development through remittance could be observed through channelizing remittance into productive investment and capital accumulation.

In addition, remittances may represent capital flows that have yet to be determined, but the verdict is still out. It is because of the importance of government policy growth, and it is worth looking at. One way to do this is to see whether remittance behavior is similar to other forms of capital flows. Expressly, we assume that remittance flows would be positive with sustainable development through economic expansion (Qamruzzaman and Jianguo, 2020b) and financial diversification (Gnangnon, 2020; Pandikasala et al., 2021). Existing literature advocates that remittances are not sufficient for economic growth but rather work in a better manner in those economies with a higher degree of openness, indicating that benefit depends on domestic institutions and the receiving country's macroeconomic environment. Kapur and Singer (2006) showed that remittance inflows appear to minimize government consumption in developed countries and validate the replacement impact between private insurance given by remittances and public insurance initially provided by government expenditure. Furthermore, remittances mainly aim to take advantage of high yields or other home country investment prospects (Kumar, 2011). Even by lower barriers to trade, greater economic access could promote an increase in remittances that fund purchases of products and services required to sustain migrant associations' projects in the home countries (Kumar, 2013; Nahar et al., 2018).

The contribution from this study to the existing literature is three-fold. First, the impact of remittances on the economy, precisely focusing on both macro aspects, including economic, financial development (Ahmed et al., 2021; Bolarinwa and Akinbobola, 2021; Ellahi and Omer, 2021), financial inclusion (Issabayev et al., 2020; Barnabe, 2021), and macro aspects, such as household consumption (Raihan et al., 2009, 2021; Kumar et al., 2021), education (Zhunio et al., 2012; Ambler et al., 2015), and social security (De Haas, 2010; Peth and Sakdapolrak, 2020) have been investigated but there is yet any conclusive evidence. However, the impact of remittances is undoubtedly acknowledged and appreciated in literature from every corner of the economy. With this study, we intended to explore fresh evidence regarding the impact of remittances on economic openness and the role of establishing financial stability by considering a panel of 40 least developed countries (LDCs) for the period spanning 1975-2018. Second, the role of remittances is critically important for both developed and developing nations, but to what extent can remittances contribute to LDCs' development? No such focused research has yet been performed in empirical estimation. The existing research gap focuses on remittances' influence on unexposed LDCs; thus, we tried to lessen that gap with this study's fresh assessment.

The study's motivation is to evaluate the impact of remittances on openness, i.e., economic and financial openness and financial stability in LDCs, with the mediating effect of capital formation and government debt from 1975 to 2018. Study findings expose positive and statistically significant effects running from remittances to openness and financial stability. Findings suggest that continual remittance inflows assist in achieving openness in the economy through economic openness and financial openness. Furthermore, in establishing financial stability the role of remittances is critically essential. The remaining structure of the manuscript is as follows. The relevant literature survey is displayed in Section Literature review: remittance, openness, and financial stability, variable definitions and the econometrical methodology are explained in Section Data and methodology of the study. Empirical model estimation and interpretation are displayed in Section Estimation and interpretation, and finally, a summary of findings and the conclusion are in Section Findings and Conclusions.

\section{LITERATURE REVIEW: REMITTANCE, OPENNESS, AND FINANCIAL STABILITY}

The theoretical literature on remittances is extensive because several scholars have proposed hypotheses explaining their position in the economy, at least informally, to inspire an empirical study. However, several of the ideas presented have a similar thread running through them. Early theories of remittances established and explained a variety of costs and advantages associated with remitting. Russell (1986) compiled a list of them. Since the whole family shares and sells off the costs and advantages of remitting, the family is the optimal study for migration and remittance issues. As a result, recent theoretical work on remittances' nature has centered on and may be classified by the potential functions of family or family interactions in influencing remittance choices. There is still controversy about the idea of enabling foreign labor mobility as a way to boost remittance inflows to developed countries (Yang and Choi, 2007; De Haas, 2010; Bellantuono et al., 2021). Developing countries fret about a "brain drain," even as remittances and commerce and investment are more than compensating for professional staff shortages abroad. A large increase in foreign migration may have significant economic advantages (Schiff and Özden, 2005). However, the adverse association between remittances and economic progress is also established in the literature; see, for instance, (Chami et al., 2003, 2005; Hakura et al., 2009; Abdih et al., 2012).

\section{Remittance and Openness}

The increasing value of remittances and their beneficial effect on the receiving countries' economic conditions give their policymakers good incentives to promote 
these flows' attractiveness. Among the potential schemes to improve these revenues, the widening of financial boundaries is a possible strategy tool for governments. By lowering the cost of remittances sent through official means or relaxing the limitation of financial flows from abroad, policymakers may significantly increase the overall amount of funds collected. Financial transparency, though, poses new costs and challenges for the receiving countries.

A study was performed to assess the impact of remittance trade openness in Nepal by applying time-series data. Study findings reveal a positive association and confirm the critical role in increasing income level through domestic trade expansion. In addition, Gnangnon (2020) gauges the impact of remittances on foreign direct investment by considering a panel of 116 countries. Study findings reveal that trade openness and foreign capital inflows are positively induced by the recipients of remittance inflows in the economy.

\section{Remittances and Financial Stability}

Remittance's role in the financial system has been extensively investigated through divers measures, such as financial inclusion (Aggarwal et al., 2006; Chowdhury, 2011; Anetor, 2019; Sobiech, 2019) and financial innovation. Despite the increasing value of remittances, little research has been done on the relationship between remittances and financial access. Unbanked remittance recipients, according to Inoue (2019), can demand secure storage of surplus money from banks and non-bank financial institutions, as well as other financial products and services. A study argued that remittances produce complementary effects in the financial sector by establishing operational efficiency and consistency through economic augmentation. Remittances prefer to work in reconstruction and restructuring in the financial sector; Mundaca (2009) advocated that the complementary role of remittances facilitates economic growth with financial efficiency. Giuliano and Ruiz-Arranz (2009) demonstrate that in countries where the financial sector is underdeveloped, remittances reduce credit restrictions and act as a replacement for financial production, boosting resource distribution and increasing economic growth.

On the other side, Mundaca (2009) specifies that financial developments could theoretically contribute to the greater use of remittances, thus encouraging progress. Aggarwal et al. (2011) indicate that remittances will directly foster non-financial growth. They found that remittances had a significant and optimistic effect on the GDP of bank deposits. Overall, the literature finds that the net effect on development seems optimistic, without considering the positive effects that remittances can have on income distribution. Ratha (2005) advocates remittance as a vital source of external capital inflows for achieving sustainability in financial progress. The study suggests that having a well-developed finance system and transport infrastructure will improve the transfer of money from one place to another and lead to increased structured transactions.
TABLE 1 | Variables definitions and notation in the equation.

\begin{tabular}{|c|c|c|}
\hline Variables & Notation & Definition \\
\hline Remittance & $\mathrm{RE}$ & Personal remittances received (\% of GDP) \\
\hline \multirow[t]{3}{*}{ Openness } & $\mathrm{FO}$ & $\begin{array}{l}\text { Financial openness is classified according } \\
\text { to three regimes (closed, neutral, or open) } \\
\text { based on the KAOPEN financial openness } \\
\text { indicator of Chinn and Ito (2008). }\end{array}$ \\
\hline & EO & $\begin{array}{l}\text { Foreign direct investment, net inflows (\% } \\
\text { of GDP) }\end{array}$ \\
\hline & & $\begin{array}{l}\text { Total trade (sum of imports and exports) } \\
\text { as a \% of GDP }\end{array}$ \\
\hline Financial stability & FS & M2 to GDP \\
\hline $\begin{array}{l}\text { Government } \\
\text { debt }\end{array}$ & $\mathrm{D}$ & $\begin{array}{l}\text { External debt stocks, long-term (DOD, } \\
\text { current US\$) }\end{array}$ \\
\hline Capital formation & GCF & Gross capital formation (\% of GDP) \\
\hline $\begin{array}{l}\text { Financial } \\
\text { development }\end{array}$ & FD & $\begin{array}{l}\text { Domestic credit to the private sector (\% of } \\
\text { GDP) }\end{array}$ \\
\hline $\begin{array}{l}\text { Economic } \\
\text { growth }\end{array}$ & Y & GDP per capita (constant 2010 US\$) \\
\hline
\end{tabular}

\section{DATA AND METHODOLOGY OF THE STUDY}

The aim of this study was to assess the impact of remittance on economic openness and financial stability in least developed countries by considering a panel of 40 countries for the period spanning 1975-2018. The selection of countries and sample period rely on data availability. As a dependent variable of the empirical estimation, remittances measured by personal remittances received (\% of GDP) were extracted from world development indicators. Regarding independent variables in the empirical assessment, the study considers economic oppressors and financial stability; see Table 1 for a summary of proxy formation of variables.

\section{Openness ( 0 )}

The terms "economic globalization" and "openness" are often interchanged. In the related literature, though, transparency is the most popular concept for capturing the increasing foreign convergence of exchange and finance. We like to use it as the term "globalization" (Amna Intisar et al., 2020). Existing metrics of economic openness, commonly interpreted as the degree to which non-domestic players may or do engage in a domestic economy, may be grouped in two ways: first, according to the form of openness- "physical" or "financial"-they seek to quantify and, second, according to the sources used, to compose the measure of openness. These sources are either aggregated economic figures (de-facto measures) or evaluations of economic transparency's structural basis, i.e., lawfully defined obstacles to exchange and financial transactions. Addressing economic openness in literature, two lines of the study available are one group of researchers have considered total trade as a percentage of GDP as a measure of EO, see Fujii (2019) and Chen et al. (2021), and simultaneously another line of study has been considering FDI inflows as a measured of EO, see Steiner 
and Saadma (2016), Baltagi et al. (2009). Furthermore, financial openness is classified according to three regimes (closed, neutral, or open) based on the KAOPEN financial openness indicator of Chinn and Ito (2008).

\section{Financial Stability}

In related literature, several proxies for financial stability have been employed, e.g., monetary aggregates such as M2 to GDP or financial intermediation indices such as the ratio of domestic credit to the private sector to GDP. However, there is no consensus on the superiority of any of these indicators to date, following the recent examples by Ang and McKibbin (2007) and Gries et al. (2009).

Apart from dependent and independent variables, the study considers government debt, gross capital formation, financial development, and economic growth as control variables. The motivation to include the variables mentioned above in the equation is to enrich the estimation efficiency and consistency. The selected variables have contributed to achieving the state of both economic and financial openness (Yasmeen et al., 2021), simultaneously triggering the growth of financial stability (Broner et al., 2011).

The generalized model based on research variables is as follows:

$$
\begin{aligned}
& X *_{i, t}=\beta_{1} X *_{i, t-1}+\beta_{2} R_{i, t}+\beta_{3} F D_{i, t}+\beta_{4} G C F_{i, t} \\
& +\beta_{5} D_{i, t}+\beta_{6} Y_{i, t}+\mu_{i, t}
\end{aligned}
$$

The above equation is dynamic due to incorporating the lagged value of the dependent variable in the equation. Here, $X^{*}$ specifies the representation of proxy measures for openness, which is measured by the KAOPEN index, FDI inflows, trade openness, and financial stability measures by M2 to GDP. R denotes remittance inflows. In the group of control variables present in the equation, FD denotes financial development, GCF stands for gross capital formation, D means external debt, and Y denotes economic growth par capital. The subscripts of $\mathrm{i}$ indicate crosssection units and $t$ for time. The descriptive statistics of research variables display in Table 2.

Several econometrical tools were applied for gauging the impact of remittances on openness and financial stability in LDCs for the period spanning 1975-2018, such as a test of heterogeneity, cross-sectional dependency, a panel unit root test following Pesaran (2007), and a conventional and error correction-based panel co-integration test (Westerlund, 2008). This study prefers to apply Generalized Moments of Methods (GMM hereafter) familiarized by Arellano and Bond (1991) and System-GMM initiated by Blundell and Bond (1998). Several benefits induce the selection of the above-mentioned econometric methodology, such as System-GMM estimation, an effective tool for dynamic panel data estimation (Baltagi et al., 2009). Furthermore, instead of other econometric methods, the GMM technique provides more efficient and reliable predictions (Baltagi, 2008). Furthermore, this approach considers the predicted association between the error term and the country fixed effects exacerbated in complex penal data, which has less time and fewer cross-sections (Nickell, 1981). The GMM methodological approach can be used to solve the potential endogeneity and heterogeneity problem. According to Omri and Sassi-Tmar (2015), the GMM also tackles omitted predictor prejudice and heteroskedasticity and produces the estimate's reliability. Resolving the present state in dynamic panel data estimation, Arellano and Bond (1991) and Arellano and Bover (1995) offered a basic approach, which was generalized and further developed by Blundell and Bond (1998), commonly known as System-GMM estimation. It is worth mentioning here that two-step GMM estimation is more efficient than single-stage estimation. The instrument validation was confirmed through the Sargan test (Sargan, 1958) and the Hausman test (Hansen and Singleton, 1982).

The generalized specification of the System-GMM at a level and after first difference are as follows:

$$
\begin{aligned}
& X *_{i, t}=\beta_{1} X *_{i, t-1}+\beta_{2} R_{i, t}+\beta_{3} F D_{i, t} \\
& +\beta_{4} G C F_{i, t}+\beta_{5} D_{i, t}+\beta_{6} Y_{i, t}+\varphi_{i t}+\mu_{i, t}
\end{aligned}
$$

The difference form is:

$$
\begin{aligned}
& X *_{i, t}-X_{i t-1}=\beta_{1}\left(X *_{i, t-1}-X_{i t-1}\right)+\beta_{2}\left(R_{i, t}-R_{i t-1}\right) \\
& +\beta_{3}\left(F D_{i, t}-F D_{i t-1}\right)+\beta_{4}\left(G C F_{i, t}-G C F_{i t-1}\right)+\beta_{5}\left(D_{i, t}-D_{i t-1}\right) \\
& +\beta_{6}\left(Y_{i, t}-Y_{i t-1}\right)+\left(\varphi_{i t}-\varphi_{i t-1}\right)+\left(\mu_{i, t}-\mu_{i, t-1}\right)
\end{aligned}
$$

\section{System-GMM-Based Panel Granger Causality Test}

For specifying directional causality between financial development, trade openness, cross-broader capital flows, and renewable energy consumption, the study followed the panel error correction model causality test discussed by Shabani and Shahnazi (2019) and Qamruzzaman and Jianguo (2020a) in their research work. A panel Granger causality test with System-GMM application was performed in two steps. In the first step, the long-run model estimation was performed with Dynamic-OLS (DOLS) to retrieve the residuals. Second, the residual obtained from DOLS estimation is used as an error correction term with the lagged first difference, which specifies long-run causality in the model. The equations for the short-run and long-run causality estimation are presented below:

$$
\begin{aligned}
& \Delta X *_{i t}=\beta_{1 i}+\sum_{k=1}^{m} \beta_{11 i k} X *_{i t-k}+\sum_{k=1}^{m} \beta_{12 i k} R_{i t-k} \\
& +\sum_{k=1}^{m} \beta_{13 i k} D_{i t-k}+\sum_{k=1}^{m} \beta_{14 i k} G C F_{i t-k}+\zeta_{1 i} E C T_{i t-1}+e_{1 i t}
\end{aligned}
$$

Where $\mathrm{p}$ represents the optimal lag length, which is determined by using Akaike's information criterion (AIC), we found that optimal lag for the estimation is 2, ECT stands for error correction term for assessing long-run causality, and $e_{i t}$ for the error term.

The underlying principle of using the System-GMM in determining a causality test with panel error correction 
TABLE 2 | Descriptive statistics.

\begin{tabular}{|c|c|c|c|c|c|c|c|c|}
\hline & EO1 & EO2 & FO & $\mathbf{R}$ & D & GCF & DCP & $\mathbf{Y}$ \\
\hline \multicolumn{9}{|c|}{ Panel-A: Descriptive statistics } \\
\hline Mean & -0.032 & 3.897 & -0.757 & 0.219 & 21.322 & 2.885 & 2.459 & 6.495 \\
\hline Median & 0.267 & 3.897 & -1.218 & 0.632 & 21.306 & 2.902 & 2.499 & 6.379 \\
\hline Maximum & 4.637 & 5.74 & 2.333 & 3.447 & 24.45 & 4.331 & 4.6 & 8.048 \\
\hline Minimum & -8.927 & -1.787 & -1.92 & -7.012 & 17.679 & -1.228 & -0.909 & 5.301 \\
\hline Std. dev. & 1.833 & 0.59 & 1.126 & 1.872 & 1.235 & 0.48 & 0.741 & 0.511 \\
\hline Skewness & -0.992 & -3.433 & 1.778 & -1.164 & -0.07 & -1.084 & -0.279 & 0.32 \\
\hline Kurtosis & 4.829 & 35.748 & 5.234 & 4.554 & 2.639 & 11.814 & 3.869 & 2.715 \\
\hline Jarque-Bera & 214.135 & 32888.9 & 518.205 & 230.35 & 4.389 & 2420.744 & 31.42 & 14.453 \\
\hline Observations & 842 & 705 & 705 & 705 & 705 & 705 & 705 & 705 \\
\hline \multicolumn{9}{|c|}{ Panel-B: Pairwise correlation } \\
\hline \multicolumn{9}{|l|}{ EO1 } \\
\hline EO2 & 0.364 & & & & & & & \\
\hline $\mathrm{FO}$ & 0.237 & 0.207 & & & & & & \\
\hline$R$ & 0.078 & 0.094 & 0.251 & & & & & \\
\hline D & 0.117 & -0.154 & -0.017 & 0.13 & & & & \\
\hline GCF & 0.219 & 0.226 & 0.012 & 0.103 & 0.302 & & & \\
\hline DCP & -0.019 & 0.29 & 0.035 & 0.276 & 0.16 & 0.465 & & \\
\hline Y & 0.12 & 0.084 & 0.219 & 0.216 & 0.093 & 0.397 & 0.336 & \\
\hline
\end{tabular}

is consistent and unbiased in estimation. On the other hand, OLS-based estimation is biased and creates an endogeneity problem in estimation (Soto, 2009; Combes et al., 2017). Therefore, other econometric techniques are required.

The Generalized Method of Moments (GMM) is a commonly used econometric methodology in panel data estimation with endogenous regressors. In the empirical literature, there are two types of GMM estimations. The first difference GMM estimation proposed by Arellano and Bond (1991) and the System-GMM estimation proposed by Arellano and Bover (1995) and further developed by Blundell and Bond (1998). The first difference GMM estimation suffers from weak instruments and small sample sizes when endogenous variables are close to a random walk (Blundell and Bond, 1998). The emergence of System-GMM estimation overcomes the first difference in GMM estimation (Arellano, 2003; Baum et al., 2007; Baltagi, 2008; Han et al., 2014). The System-GMM performs by estimating two system equations. First, the original levels equation with a suitable lagged first difference is used as an instrument and the first difference equation with a suitable lagged level is used as an instrument. Second, the application of System-GMM reduces the finite sample bias and increases consistency in estimation (Blundell and Bond, 1998). Therefore, we performed System-GMM estimation by using a prior developed Equation (4).

The short-run and long-run causality, after System-GMM estimation, will be identified by applying a standard Wald test. The null hypothesis of no causality will be rejected if the coefficients of $\beta_{11}$ to $\beta_{44}=0$ and the coefficient of statistically significant ECT ascertain the existence of long-run causality in the equation.

\section{ESTIMATION AND INTERPRETATION}

\section{Cross-Sectional Dependency Test, Heterogeneity, Panel Unit Root Test, and Co-integration}

Before performing the econometric empirical model estimation for gauging the impact of remittance on openness and financial stability in least developed counties for the period spanning 1976-2018, the study performs an elementary assessment through cross-sectional dependency (CSD), the heterogeneity test, and the panel unit root test with both the first and second generation and the co-integration test for long-run association. The results of cross-sectional dependency are exhibited in Table 3. The associated $p$-value of test statistics ascertains that research units share a familiar dynamic among them. In addition to the CSD test, the study intends to evaluate heterogeneity following the framework familiarized by Pesaran and Yamagata (2008). The estimation results are displayed in Table 3, columns 5-6 with two coefficients, i.e., $\Delta$ and adj $\Delta$. Study findings establish the availability of heterogeneous properties in the selected dataset by rejecting the null hypothesis of homogeneity at a $1 \%$ level of significance.

Following, the study moves to assess the order of the integration of the variable by performing panel unit root tests following Levin et al. (2002) known as an LLC test, Im et al. (2003) - the IPS test, and the Fisher-ADF initiated by Maddala and $\mathrm{Wu}$ (1999) which have the null hypothesis that all the panel 
TABLE 3 | Results of cross-sectional dependency test and heterogeneity test.

\begin{tabular}{|c|c|c|c|c|c|c|}
\hline & \multicolumn{4}{|c|}{ Cross-sectional dependency test } & \multicolumn{2}{|c|}{ Heterogeneity test } \\
\hline & [1] & [2] & [3] & [4] & [5] & [6] \\
\hline EO1 & $322.981^{\star \star \star}$ & $25.44^{\star \star \star}$ & $164.06^{\star \star \star}$ & $35.201^{\star \star \star}$ & 91.11 & 75.373 \\
\hline FS & $182.813^{\star \star \star}$ & $19.23^{\star \star \star}$ & $150.55^{\star \star \star}$ & $28.416^{\star \star \star}$ & 42.221 & 71.551 \\
\hline$R$ & $241.649^{\star \star \star}$ & $17.68^{\star \star \star}$ & $242.59^{\star \star \star}$ & $35.167^{\star \star \star}$ & 34.901 & 87.925 \\
\hline GCF & $245.592^{\star \star \star}$ & $30.97^{\star \star \star}$ & $138.36^{\star \star}$ & $54.619^{\star \star \star}$ & 70.358 & 131.289 \\
\hline$F D$ & $255.103^{\star \star \star}$ & $34.54^{\star \star \star}$ & $147.35^{\star \star \star}$ & $50.268^{\star \star \star}$ & 84.339 & 91.038 \\
\hline D & $295.589^{\star \star \star}$ & $34.01^{\star \star \star}$ & $184.09^{\star \star \star}$ & $39.269^{\star \star \star}$ & 74.327 & 136.052 \\
\hline
\end{tabular}

The superscript of ${ }^{\star \star \star}$ denotes the level of significance at a $1 \%$, respectively.

TABLE 4 | Test of unit root rest-first generation.

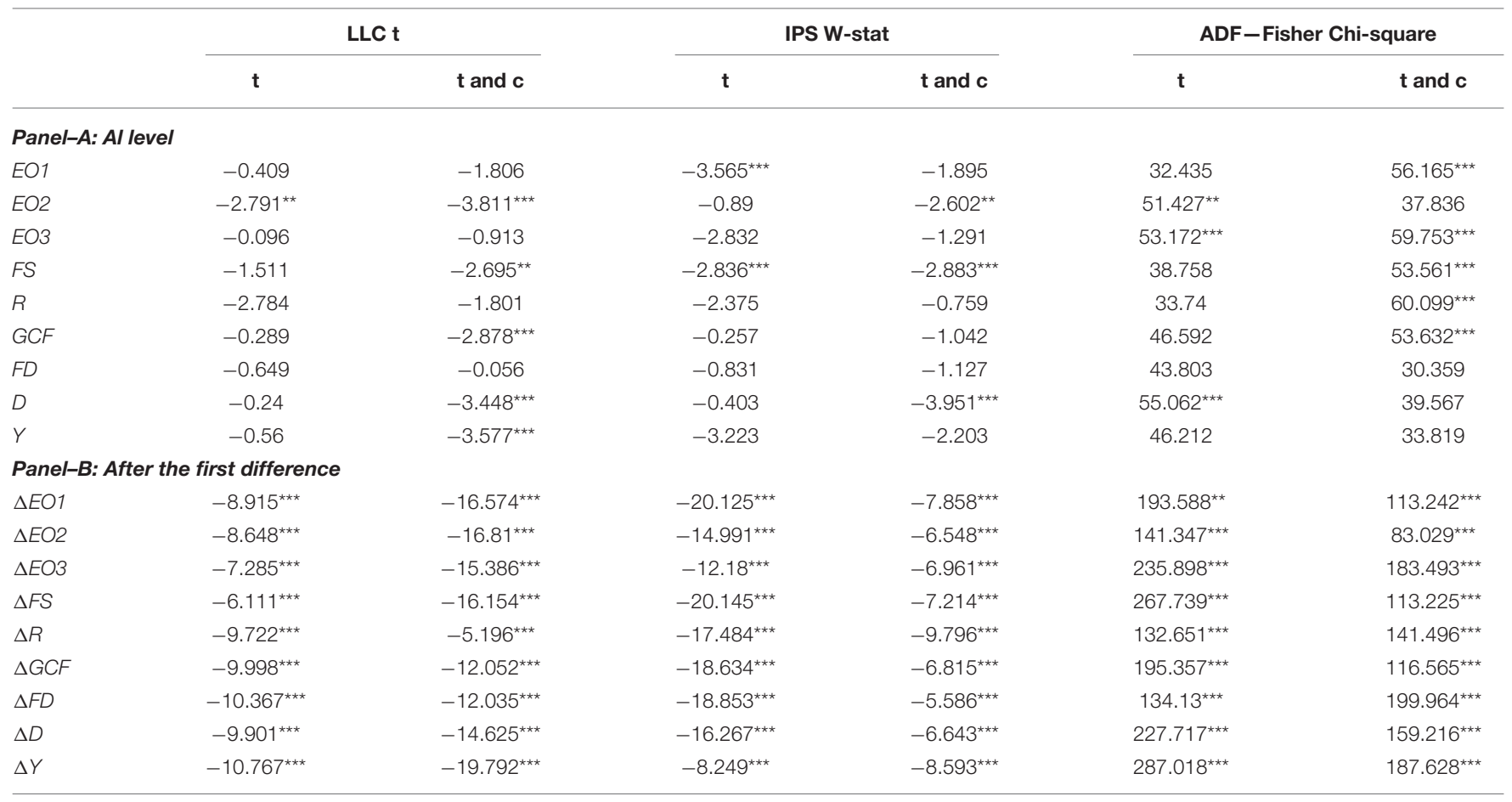

The superscript of ${ }^{* *},{ }^{* \star \star}$ denotes the level of significance at a $5 \%$ and $1 \%$, respectively.

data contain a unit root. Results of the panel unit root tests are displayed in Table 4. Study findings established that variables are stationary either at a level or after the first difference; neither variable is stationary after the second difference.

Furthermore, considering the CSD test results, the study performs second generation panel unit root tests, commonly known as CIPS and CADA proposed by Pesaran (2007), which can efficiently handle the presence of typical dynamism. Results of the panel unit root tests are exhibited in Table 5. It is apparent from study findings that variables are integrated in a mixed order. However, neither variable is stationary after the second difference.

In the next step, the long-run association between remittances, financial stability, and openness were investigated by performing a panel co-integration test offered by Pedroni (2001, 2004). Results of the panel co-integration test are displayed in Table 6, consisting of four empirical models based on proxy measures of openness and financial stability (see Table 1). The test statistics with the Pedroni panel co-integration test produce 11 outcomes. Most test outputs are statistically significant at a $1 \%$ 
TABLE 5 | Unit root test-second generation.

\begin{tabular}{|c|c|c|c|c|c|c|c|c|}
\hline \multirow[b]{2}{*}{ EO1 } & \multicolumn{4}{|c|}{ CIPS } & \multicolumn{4}{|c|}{ CADF } \\
\hline & C & CandT & C & CandT & C & CandT & C & CandT \\
\hline EO2 & -1.485 & $-1.629^{\star \star}$ & $-2.451^{\star \star \star}$ & $-4.406^{\star \star \star}$ & -1.344 & $-2.005^{\star \star \star}$ & $-2.381^{\star \star \star}$ & $-6.347^{\star \star \star}$ \\
\hline EO3 & $-1.633^{\star \star}$ & -1.11 & $-6.568^{\star \star \star}$ & $-5.241^{\star \star \star}$ & -1.359 & $-2.518^{\star \star \star}$ & $-4.034^{\star \star \star}$ & $-4.181^{\star \star \star}$ \\
\hline GCF & -2.261 & $-2.815^{\star \star \star}$ & $-6.768^{\star \star \star}$ & 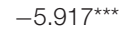 & $-2.271^{\star \star \star}$ & $-1.972^{\star \star}$ & $-4.652^{\star \star \star}$ & $-5.516^{\star \star \star}$ \\
\hline FD & $-2.938^{\star \star \star}$ & $-2.89^{\star \star \star}$ & $-5.056^{\star \star \star}$ & $-3.074^{\star \star \star}$ & $-2.303^{\star \star \star}$ & -1.58 & $-6.907^{\star \star \star}$ & $-2.571^{\star \star \star}$ \\
\hline D & -1.307 & $-2.734^{\star \star \star}$ & $-6.081^{\star \star \star}$ & $-3.887^{\star \star \star}$ & $-2.995^{\star \star \star}$ & $-1.967^{\star \star}$ & $-3.751^{\star \star \star}$ & $-5.757^{\star \star \star}$ \\
\hline Y & $-2.956^{\star \star \star}$ & $-2.953^{\star \star \star}$ & $-2.028^{\star \star \star}$ & $-2.686^{\star \star \star}$ & -1.153 & -1.574 & $-3.126^{\star \star \star}$ & $-5.75^{\star \star \star}$ \\
\hline
\end{tabular}

The superscript of ${ }^{* *},{ }^{* * \star}$ denotes the level of significance at a $5 \%$ and $1 \%$, respectively.

TABLE 6 | Panel co-integration test.

Models

[1] [2] [3]

\begin{tabular}{|c|c|c|c|c|}
\hline \multicolumn{5}{|c|}{ Panel-A: Pedroni residual co-integration test } \\
\hline Panel v-Statistic & 1.368 & 1.459 & $2.708^{\star \star \star}$ & 1.403 \\
\hline Panel rho-Statistic & $-4.502^{\star \star \star}$ & $-5.711^{\star \star \star}$ & $-5.407^{\star \star \star}$ & $-5.132^{\star \star \star}$ \\
\hline Panel ADF-Statistic & $-4.529^{\star \star \star}$ & -0.695 & $-4.417^{\star \star \star}$ & $-5.122^{\star \star \star}$ \\
\hline Panel v-Statistic & -0.721 & -1.262 & $-5.855^{\star \star \star}$ & -1.103 \\
\hline Panel rho-Statistic & $-7.358^{\star \star \star}$ & $-7.182^{\star \star \star}$ & $-0.215^{\star \star \star}$ & $-11.84^{\star \star \star}$ \\
\hline Panel ADF-Statistic & $-11.063^{\star \star \star}$ & $-7.819^{\star \star \star}$ & $-8.558^{\star \star \star}$ & -0.859 \\
\hline Group rho-Statistic & $-11.989^{\star \star \star}$ & $-6.193^{\star \star \star}$ & $-8.025^{\star \star \star}$ & $-7.127^{\star \star \star}$ \\
\hline Group PP-Statistic & $-7.508^{\star \star \star}$ & $-11.099^{\star \star \star}$ & $-6.023^{\star \star \star}$ & -0.914 \\
\hline Group ADF-Statistic & $-3.846^{\star \star \star}$ & $-3.677^{\star \star \star}$ & -2.599 & -2.705 \\
\hline \multicolumn{5}{|c|}{ Panel-B: Kao residual co-integration test } \\
\hline ADF & $-2.9726^{\star \star \star}$ & $-1.5814^{\star \star \star}$ & $-2.8971^{\star \star \star}$ & $-5.8228^{\star \star \star \star}$ \\
\hline
\end{tabular}

The superscript of ${ }^{* *},{ }^{* * *}$ denotes the level of significance at a $5 \%$ and $1 \%$, respectively.

level, indicating a long-run association in the equation. This conclusion applies to all four mode estimations. Furthermore, the ADF test statistics for gauging the long-run association were statistically significant at a $1 \%$ level, implying the rejection of the null hypothesis of no co-integration. Hence, it has convincingly established the availability of the long-run association between remittances, financial stability, and openness in least developed countries.

Furthermore, the study performed the newly emerged panel co-integration test with the error correction term familiarized by Westerlund (2008). Results of the panel co-integration test are reported in Table 7 It is apparent from the test statistics that all the associated $p$-values are statistically significant at a $1 \%$ level. These findings suggest the existence of a long-run association between remittances, financial stability, and openness.

The following results of empirical model estimation following GMM and System-GMM frameworks are displayed in Table 8.
TABLE 7 | Results of Westerlund (2008) panel co-integration test.

\begin{tabular}{lcccc}
\hline Empirical model & Gt & Ga & Pt & Pa \\
\hline$[1]$ & $-11.373^{\star \star \star}$ & $-13.71^{\star \star \star}$ & $-15.911^{\star \star \star}$ & $-13.507^{\star \star \star}$ \\
{$[2]$} & $-4.524^{\star \star \star}$ & $-8.826^{\star \star \star}$ & $-11.623^{\star \star \star}$ & $-9.02^{\star \star \star}$ \\
{$[3]$} & $-7.872^{\star \star \star}$ & $-8.02^{\star \star \star}$ & $-12.848^{\star \star \star}$ & $-6.014^{\star \star \star}$ \\
{$[4]$} & $-9.831^{\star \star \star}$ & $-14.15^{\star \star \star}$ & $-10.371^{\star \star \star}$ & $-7.206^{\star \star \star}$
\end{tabular}

The superscript of ${ }^{\star \star *}$ denotes the level of significance at a $1 \%$, respectively.

Coefficients for GMM estimation are reported in Panel-A and System-GMM coefficients are in Panel-B.

The coefficient of remittances exposes positive statistically significant impacts running toward the measures of openness, i.e., economic openness (a coefficient of 0.128 in column 1 and a coefficient of 0.248 in column 2) and financial openness 
TABLE 8 | Results of model estimation with GMM and System-GMM.

[1]

$$
\begin{gathered}
0.128^{\star \star \star}[16.206] \\
0.034^{\star \star}[11.742] \\
-0.022^{\star \star}[-4.754] \\
0.027^{\star \star \star}[2.061] \\
0.066^{\star \star \star}[4.382]
\end{gathered}
$$

$0.071^{\star \star \star}[105.826]$

$\mathrm{EO}(-1)$

FDIII(-1)

Flo(-1)

FS(-1)

$\mathrm{R}$

GCF

$D$

FD

Y

$\mathrm{AR}(1)$

$A R(2)$

Sargan test

Hansen test ( $p$-value)
[2]

[3]

[4]

$$
\begin{gathered}
0.137^{\star \star \star}[41.985] \\
0.098^{\star \star}[22.861] \\
-0.029^{\star \star \star}[-6.618] \\
0.061^{\star \star}[1.892] \\
0.033^{\star \star \star}[12.979]
\end{gathered}
$$

$0.043^{\star \star \star}[25.178]$

$0.191^{\star \star *}[5.096]$

$0.053^{\star \star \star}[6.115]$

$0.081^{\star *}[3.301]$

$0.099^{\star \star \star}[27.014]$

The superscript of ${ }^{*},{ }^{* *},{ }^{* * *}$ denotes the level of significance at a $10 \%, 5 \%$, and $1 \%$, respectively.

(a coefficient of 0.137 ) and financial stability (a coefficient of 0.043 in column 4). Study findings suggest that continual inflows of remittances in the economy can cause economic openness and financial openness to thrive and establish financial stability in the financial system. Furthermore, the System-GMM estimation establishes the similar line of association between remittances, openness, and financial stability, that is, positive effects running from remittances to openness (see, panel $-\mathrm{B}$, a coefficient of 0.155 in column 1 ; a coefficient of 0.074 in column 2; a coefficient of 0.116 in column 3 ) and financial stability (a coefficient of 0.061). Study findings establish that for boosting and augmenting openness in the economy through economic openness and financial openness and achieving financial stability in the financial system, remittance inflows play a critical role. Study findings are in line with Beine et al. (2012) and Bang et al. (2015). Only "more open" nations seemed to benefit from remittances (Dastidar, 2017), implying that remittances are insufficient for development on their own. The size of the benefit is determined by the recipient country's internal institutions and macro-economic situation. Unlike "less open" nations, "more open" nations have superior institutions and financial markets to take advantage of remittance revenue and channel it into successful investments, accelerating economic development.

The impact of domestic gross capital formation exposes a positive statistically significant association with economic openness (a coefficient of 0.034 in column 1 and a coefficient of 0.053 in column 2), financial openness (a coefficient of 0.098), and financial stability (a coefficient of 0.19) in GMM estimation. Moreover, a similar association line was established with SystemGMM estimation, that is positive statistically significant impacts running from capital formation to economic and financial openness and financial stability. Study findings are supported by empirical literature; see Solarin and Shahbaz (2015), Yasmeen et al. (2021), Avelino et al. (2005). On the other hand, the elasticity of government debt disclosed a negative statistically significant association with openness and financial stability, available in empirical model estimation.

The directional association between remittance inflows, openness, and financial stability is investigated by performing the Granger causality test with System-GMM specification. The panel causality test results are displayed in Table 9 with four outputs based on different proxies of openness and financial stability in the equation.

The summary results of directional causality are displayed in Table 10. For column 1, economic openness is measured by the KAOPEN index and results disclose bidirectional causality running between remittance inflows and economic openness $[\mathrm{EO} \leftarrow \rightarrow \mathrm{R}]$ and government debt and economic openness $[\mathrm{EO} \leftarrow \rightarrow \mathrm{D}$ ]. Furthermore, unidirectional causality running from financial development to economic openness $[\mathrm{FD} \rightarrow \mathrm{EO}]$ and economic openness to economic growth $[\mathrm{EO} \rightarrow \mathrm{Y}]$ are apparent. For column 2, economic openness is measured by trade openness. The study reveals unidirectional causality running from economic openness to remittances $[\mathrm{EO} \rightarrow \mathrm{R}]$, government debt to economic openness $[\mathrm{D} \rightarrow \mathrm{EO}]$, and economic openness to economic growth $[\mathrm{OE} \rightarrow \mathrm{Y}]$.

The causal effects of financial openness, measured by inflows of FDI, are reported in column 3. The study divulges bidirectional causality running between remittances and financial openness $[\mathrm{R} \longleftrightarrow \rightarrow \mathrm{FO}$ ], government debt and financial openness 
TABLE 9 | Granger causality test with System-GMM specification.

\begin{tabular}{|c|c|c|c|c|c|c|c|}
\hline & EO & $\mathbf{R}$ & FD & D & GCF & $\mathbf{Y}$ & ЕСТ(-1) \\
\hline \multicolumn{8}{|c|}{ Panel-A: Dependent variable- openness measured by KAOPEN index } \\
\hline EO & - & $8.504^{\star \star}$ & 13.542 & $6.321^{*}$ & 1.311 & 2.424 & $-0.531^{\star \star \star}$ \\
\hline $\mathrm{R}$ & $7.928^{\star \star}$ & - & 2.192 & 0.205 & 0.644 & 0.734 & -0.045 \\
\hline FD & 0.76 & 1.62 & - & $5.999^{*}$ & $7.236^{\star \star}$ & $5.896^{\star \star}$ & 0.189 \\
\hline D & 2.696 & $4.312^{*}$ & 3.037 & - & $5.064^{*}$ & $25.497^{\star \star \star}$ & 0.929 \\
\hline \multicolumn{8}{|c|}{ Panel-B: Dependent variable-openness measured by FDI inflows } \\
\hline EO & - & $11.376^{\star \star \star}$ & 1.062 & $6.919^{\star \star}$ & 0.242 & 1.493 & $-0.613^{\star \star \star}$ \\
\hline$R$ & $6.896^{\star \star}$ & - & $7.34^{\star \star}$ & 0.033 & 3.04 & $5.164^{\star \star}$ & 0.651 \\
\hline FS & 0.791 & $3.792^{*}$ & - & $3.567^{\star}$ & $3.727^{*}$ & 2.557 & $-0.245^{\star \star \star}$ \\
\hline D & $9.613^{\star \star \star}$ & $10.181^{\star \star \star}$ & 2.298 & - & 1.538 & $13.992^{\star \star \star}$ & 0.155 \\
\hline $\mathrm{FO}$ & 0 & 0.998 & $4.212^{*}$ & $18.355^{\star \star \star}$ & $18.972^{\star \star \star}$ & 0.603 & $-0.201^{\star \star \star}$ \\
\hline R & $12.874^{\star \star \star}$ & 0 & $10.289^{\star \star \star}$ & 0.434 & $6.774^{\star \star}$ & $6.989^{\star \star}$ & $-0.172^{\star \star \star}$ \\
\hline FS & $4.487^{\star}$ & 2.044 & 0 & $3.683^{\star}$ & $13.931^{\star \star \star}$ & 1.07 & 0.421 \\
\hline D & $10.169^{\star \star \star}$ & 2.536 & 2.351 & 0 & 2.752 & 1.749 & 0.557 \\
\hline GCF & $6.333^{\star \star}$ & $6.841^{\star \star}$ & 1.561 & 2.595 & 0 & 1.404 & 0.248 \\
\hline Y & $4.037^{*}$ & 2.203 & $29.003^{\star \star \star}$ & 0.689 & $9.303^{\star \star \star}$ & 0 & $-0.445^{\star \star \star}$ \\
\hline \multicolumn{8}{|c|}{ Panel-D: Dependent variable-financial stability } \\
\hline FS & - & $12.697^{\star \star}$ & $11.591^{\star \star \star}$ & 1.65 & 0.572 & $19.595^{\star \star \star}$ & $-0.593^{\star \star \star}$ \\
\hline R & $27.83^{\star \star \star}$ & - & 0.23 & 1.697 & $3.259^{*}$ & $16.647^{\star \star \star}$ & -0.066 \\
\hline FS & $7.495^{\star \star}$ & $4.463^{*}$ & - & 0.436 & $3.436^{*}$ & $5.542^{\star \star}$ & 0.561 \\
\hline D & $5.206^{\star \star}$ & 1.423 & 4.75 & - & 0.408 & 0.658 & 0.284 \\
\hline
\end{tabular}

The superscript of ${ }^{*}{ }^{* *},{ }^{* * \star}$ denotes the level of significance at a 10\%, 5\%, and $1 \%$, respectively.

[D $\rightarrow$ FO], financial development and financial openness $[\mathrm{FD} \leftarrow \rightarrow \mathrm{FO}]$, and domestic capital formation and financial openness [GCF $\leftrightarrow$ FO]. Furthermore, unidirectional causality running from financial openness to economic growth $[\mathrm{FO} \rightarrow \mathrm{Y}]$ is apparent. A directional causal association with financial stability as a deepened variable is displayed in column 4 . Study findings reveal bidirectional causality running between remittance and financial stability $[\mathrm{R} \leftarrow \rightarrow F S$, financial stability and government debt $[\mathrm{F} \leftarrow \mathrm{D}]$, and financial stability and economic growth $[\mathrm{Y} \leftarrow \rightarrow \mathrm{FS}]$. Moreover, the study unveils unidirectional causality running from financial development to financial stability $[\mathrm{FD} \leftarrow \mathrm{FS}]$ and financial stability to gross capital formation $[\mathrm{FS} \rightarrow \mathrm{GCF}]$.

In a nutshell, directional causality exposes remittance inflows in the economy that play a critical role in the thriving process of augmenting economic openness, financial openness, and financial stability. This suggests that efficient channelizing of remittances in the economy can result in broader aspects for macro development.

\section{Robustness Test}

Next, the study performs an empirical model coefficients robustness test by implementing the dynamic fixed effects model introduced by Alcántara and Padilla (2009) in panel form. Study findings reveal that each co-efficients' sign and significance align with System-GMM estimation, which is the study's prime output (please see, Table 11).

\section{FINDINGS AND CONCLUSION}

The role of remittances in the economy has been extensively investigated by considering diverse facts from both micro and macro perspectives, but any conclusive relationships are yet to be exposed. The impact of remittances on the economy immensely relies upon the socio-economic status of the countries. The study evaluates remittances' role in promoting openness: economic openness and financial openness and financial stability in least developed countries for the period spanning 1975-2018. The study implements several econometrical tools to gauge the impact of remittances, such as panel unit root tests following Pesaran (2007), error correction-based panel contention test following Westerlund (2008), GMM and System-GMM for elasticity derivation, and causality with System-GMM specificity by following Arellano and Bover (1995) and Blundell and Bond (1998). The key findings of the study are stated below: 
TABLE 10 | Summary results of causality test.

\begin{tabular}{|c|c|c|c|c|}
\hline Causalities & [1] & [2] & [3] & [4] \\
\hline$X \leftarrow \neq \rightarrow R$ & $\leftarrow$ & $\rightarrow$ & $\leftarrow$ & $\leftarrow$ \\
\hline $\mathrm{X} \leftarrow \neq \rightarrow \mathrm{DEBT}$ & $\leftarrow$ & $\leftarrow$ & $\leftarrow$ & $\leftarrow$ \\
\hline $\mathrm{X} \leftarrow \neq \rightarrow \mathrm{GCF}$ & $\leftarrow$ & $\leftarrow$ & $\leftarrow$ & $\rightarrow$ \\
\hline $\mathrm{X} \leftarrow \neq \rightarrow \mathrm{FD}$ & $\leftarrow$ & na & $\leftarrow \rightarrow$ & $\leftarrow$ \\
\hline$X \leftarrow \neq \rightarrow Y$ & $\rightarrow$ & $\rightarrow$ & $\rightarrow$ & $\leftarrow \rightarrow$ \\
\hline $\mathrm{R} \leftarrow \neq \rightarrow \mathrm{FD}$ & na & $\leftarrow$ & $\leftarrow$ & $\rightarrow$ \\
\hline $\mathrm{R} \leftarrow \neq \rightarrow \mathrm{DEBT}$ & $-\rightarrow$ & $\rightarrow$ & na & na \\
\hline $\mathrm{R} \leftarrow \neq \rightarrow \mathrm{GCF}$ & $\rightarrow$ & na & $\leftarrow \rightarrow$ & $\leftarrow \rightarrow$ \\
\hline $\mathrm{R} \leftarrow \neq \rightarrow \mathrm{Y}$ & $\rightarrow$ & $\leftarrow \rightarrow$ & $\leftarrow$ & $\leftarrow \rightarrow$ \\
\hline $\mathrm{FD} \leftarrow \neq \rightarrow \mathrm{DEBT}$ & $\leftarrow$ & $\leftarrow$ & $\leftarrow$ & \\
\hline $\mathrm{FD} \leftarrow \neq \rightarrow \mathrm{GCF}$ & $\leftarrow$ & $\leftarrow$ & $\leftarrow$ & $\leftarrow$ \\
\hline $\mathrm{FD} \leftarrow \neq \rightarrow \mathrm{Y}$ & $\leftarrow$ & $\rightarrow$ & $\rightarrow$ & $\leftarrow$ \\
\hline $\mathrm{DEBT} \leftarrow \neq \rightarrow \mathrm{GCF}$ & $\leftarrow$ & na & na & na \\
\hline DEBT $\leftarrow \neq \rightarrow \mathrm{Y}$ & $\leftarrow$ & $\leftarrow$ & na & na \\
\hline $\mathrm{GCF} \leftarrow \neq \rightarrow \mathrm{Y}$ & $\longleftrightarrow$ & $\longleftrightarrow$ & $\rightarrow$ & na \\
\hline
\end{tabular}

$\leftarrow \rightarrow$ explains bidirectional causality, $\rightarrow$ denotes unidirectional causality, and na means no causality between them.

First, the cross-sectional dependency test results confirm the presence of common dynamics among the research variable units. Moreover, the heterogeneity test establishes the rejection of homogeneity among units of the study. Second, referring to panel unit root test results, it is apparent that variables are integrated in a mixed order, indicating that they are stationary either at a level, I (0), and/or after first difference I (1), but neither variable is stationary after second difference.

Second, the long-run association in the empirical model is investigated through a panel co-integration test following Kao (1999), Pedroni (2004), and Westerlund (2008). The associated $p$-value of test statistics rejects the null hypothesis of "no co-integration," implying that the common co-movement and dynamic available in the equation is apparent in the long run.

Third, empirical model estimation with GMM and SystemGMM exposes positive statistically significant effects running from remittance inflows to the measure of openness, i.e., economic openness and financial openness. These findings are in line with Beine et al. (2012). The greater the volume of remittances obtained by a government, the more likely it is to be financially open. The beneficial impact of remittance is statistically important and economically significant. Counterfactual tests prove that the risk of being financially open is higher in countries that obtain a significant amount of remittances. Foad (2010) postulates that remittance inflows result in a positive acceleration in domestic trade, thus allowing trade liberalization by boosting economic activities due to trade openness.

Moreover, the positive statistically significant association is established between remittance inflows and financial stability which is supported by empirical studies, see Ratha (2005, 2007), Ratha and Mohapatra (2007), De and Ratha (2012). Recipients often invest in remittances, particularly in countries with stable economic policies. Policy reform and the easing of foreign exchange restrictions could have facilitated the usage of remittances (Muneeb et al., 2021). Countries could improve remittance inflows by improving financial sector infrastructure and promoting foreign travel, putting more funds into structured networks. Domestic capital formation's impact reveals a statistically significant positive association with openness and financial stability, observed in econometric model estimation. Study findings suggest that capital adequacy in the economy acts as a motivational factor for boosting economic expansion in both economic openness and financial openness.

Furthermore, capital formation fosters the financial sector's growth, assisting in achieving stability in the financial sector in the long run. On the other hand, excessive growth relies on the government's external debt which adversely causes financial openness and financial stability. However, a statistically insignificant association is established with economic openness. Therefore, the study finding suggests that the government's external debt indicates domestic inefficiency for capital formation, and debt excessiveness has an immense disadvantageous consequence for the economy. Furthermore, external debt causes instability in the exchange rate and domestic consumption and eventually instability in the economy (Kumar, 2019).

Fourth, the results of directional causality establish a feedback hypothesis that explains the causality between remittance and openness $[\mathrm{EO} \leftarrow \rightarrow \mathrm{R} ; \mathrm{FO} \leftarrow \rightarrow \mathrm{R}]$ and remittance and financial stability $[\mathrm{RF} \leftarrow \rightarrow \mathrm{S}]$. Study findings suggest that remittance inflows are critical for accelerating economic and financial openness, indicating that migrants prefer to remit their earnings to the home economy with a perceived belief that investment opportunity is available with a stable financial sector.

On top of the above, remittances' role is significantly crucial for overall economic progress, including economic openness, financial openness, and financial stability, especially

TABLE 11 | Results of dynamic fixed effects: Remittance effects on openness and financial stability.

\begin{tabular}{|c|c|c|c|c|c|c|c|c|}
\hline $\mathrm{R}$ & $0.028^{\star \star \star}$ & [14.751] & 0.289531 & [7.150] & -0.14838 & [-1.57803] & -0.00935 & {$[-1.481]$} \\
\hline DCP & $0.082^{\star \star \star}$ & [12.413] & -0.57102 & {$[-4.997]$} & -0.42021 & {$[-1.64707]$} & 0.061169 & [3.434] \\
\hline DEBT & $0.013^{\star \star}$ & [5.567] & 0.068881 & [0.760] & -0.07384 & {$[-0.364]$} & 0.00474 & [0.339] \\
\hline GCF & $-0.221^{\star \star \star}$ & {$[-3.363]$} & $0.752^{* \star *}$ & [4.954329] & 0.49206 & [1.666] & 0.199474 & [8.459] \\
\hline Y & $0.413^{\star \star \star}$ & [3.1931] & $2.444^{\star \star \star}$ & [7.545026] & 3.949192 & [5.223] & 0.261332 & [5.219] \\
\hline C & $-6.956^{\star \star \star}$ & {$[-8.072]$} & -22.9405 & {$[-11.2933]$} & -23.7527 & {$[-5.742]$} & 1.558031 & [4.780] \\
\hline
\end{tabular}

$X^{\star}(-1)$ denotes the lagged value of the dependent variable in the equation. The superscript of ${ }^{\star \star \star}$ denotes the level of significance at a $1 \%$, respectively. 
in least developing countries. To avail the best possible results from remittances in LDCs, it is imperative to concentrate on the management and efficient channelization of migrants' remittances into productive areas. This can be through financial reformation, efficient intermediation, institutional development, and, most importantly, government intention. It is suggested that remittances from migrants can be intensified by offering motivational incentives such as a reduction of exchange control policies, financial incentives for remittance recipients, and congenial investment ambiance in the financial sectors. In addition, countries might improve remittance flows and transfer more cash into formal channels by enhancing financial infrastructure and enabling international travel.

Furthermore, facilitating international labor mobility is an even more important-and contentious-method of boosting remittance inflows to poorer nations. Increased international migration might provide significant advantages to the global economy. On the other hand, developed nations are apprehensive of loosening immigration restrictions, fearing that it would boost competition in local employment markets and place a budgetary burden on local taxpayers. Developed nations are also concerned that mass immigration would corrode cultural norms and jeopardize national security.

The empirical study does not have an inherent limitation in methodological assessment or factor integration in the model. However, future studies can be performed with non-linear assessment, which is extensively considered an empirical estimation. Furthermore, the incorporation of the variable, namely economic policy uncertainty has been extensively considered in assessing the impact of macro fundamentals, see (Adams et al., 2020; Udi et al., 2020; Jia et al., 2021; Xu et al., 2021) thus it is

\section{REFERENCES}

Abdih, Y., Chami, R., Dagher, J., and Montiel, P. (2012). Remittances and institutions: are remittances a curse? World Dev. 40, 657-666. doi: 10.1016/j.worlddev.2011.09.014

Adams, S., Adedoyin, F., Olaniran, E., and Bekun, F. V. (2020). Energy consumption, economic policy uncertainty and carbon emissions; causality evidence from resource rich economies. Econ. Anal. Policy 68, 179-190. doi: 10.1016/j.eap.2020.09.012

Aggarwal, R., Demirguc-Kunt, A., and Martinez Peria, M. S. (2006). Do workers' remittances promote financial development? the world bank. J. Develop. Econ. 96, 255-264. doi: 10.1596/1813-9450-3957

Aggarwal, R., Demirgüç-Kunt, A., and Peria, M. S. M. (2011). Do remittances promote financial development? J. Develop. Econ. 96, 255-264. doi: 10.1016/j.jdeveco.2010.10.005

Ahmed, S. S., Farooq, S., Ali, R. M., and Iqbal, S. (2021). Remittance and economic growth: South Asian perspective. syed shoeb ahmed, sumair farooq, raja muhammad ali and sobia iqbal, remittance and economic growth: South Asian perspective. Int. J. Manage. 11:2020. doi: 10.34218/IJM.11.12.20 20.075

Alcántara, V., and Padilla, E. (2009). Input-output subsystems and pollution: an application to the service sector and $\mathrm{CO}_{2}$ emissions in Spain. Ecol. Econ. 68, 905-914. doi: 10.1016/j.ecolecon.2008.07.010

Ambler, K., Aycinena, D., and Yang, D. (2015). Channeling remittances to education: a field experiment among migrants from El Salvador. suggested for a future study. It may create an avenue for exploring new insights by incorporating EPU in the empirical assessment.

\section{DATA AVAILABILITY STATEMENT}

The original contributions presented in the study are included in the article/Supplementary Material, further inquiries can be directed to the corresponding authors.

\section{AUTHOR CONTRIBUTIONS}

MM: Introduction, methodology, and first draft preparation. MQ: Introduction, methodology, empirical model estimation, and final preparation. All authors contributed to the article and approved the submitted version.

\section{ACKNOWLEDGMENTS}

We would like to express our heartfelt gratitude's to the handling editor for his kind assistance and support during the peer review process. We are also very grateful to two reviewers for their constructive suggestions and comments that were very useful for transforming the present form of the manuscript.

\section{SUPPLEMENTARY MATERIAL}

The Supplementary Material for this article can be found online at: https://www.frontiersin.org/articles/10.3389/fpsyg. 2021.696600/full\#supplementary-material

Am. Econ. J. Appl. Econ. 7, 207-232. doi: 10.1257/app.201 40010

Amna Intisar, R., Yaseen, M. R., Kousar, R., Usman, M., and Makhdum, M. S. A. (2020). Impact of trade openness and human capital on economic growth: a comparative investigation of Asian countries. Sustainability 12:2930. doi: $10.3390 /$ su12072930

Anetor, F. O. (2019). Remittance and economic growth nexus in Nigeria: does financial sector development play a critical role? Int. J. Manage. Econ. Soc. Sci. 8, 116-135. doi: 10.32327/IJMESS/8.2.2019.8

Ang, J. B., and McKibbin, W. J. (2007). Financial liberalization, financial sector development and growth: evidence from Malaysia. J. Dev. Econ. 84, 215-233. doi: 10.1016/j.jdeveco.2006.11.006

Arellano, M. (2003). Panel Data Econometrics. Oxford: Oxford university press.

Arellano, M., and Bond, S. (1991). Some tests of specification for panel data: monte Carlo evidence and an application to employment equations. Rev. Econ. Stud. 58, 277-297. doi: 10.2307/2297968

Arellano, M., and Bover, O. (1995). Another look at the instrumental variable estimation of error-components models. J. Econom. 68, 29-51. doi: 10.1016/0304-4076(94)01642-D

Avelino, G., Brown, D. S., and Hunter, W. (2005). The effects of capital mobility, trade openness, and democracy on social spending in Latin America, 1980-1999. Am. J. Pol. Sci. 49, 625-641. doi: 10.1111/j.1540-5907.2005. 00146.x

Baltagi, B. H. (2008). Forecasting with panel data. J. Forecast. 27, 153-173. doi: $10.1002 /$ for. 1047 
Baltagi, B. H., Demetriades, P. O., and Law, S. H. (2009). Financial development and openness: evidence from panel data. J. Dev. Econ. 89, 285-296. doi: 10.1016/j.jdeveco.2008.06.006

Bang, J. T., Mitra, A., and Wunnava, P. V. (2015). Financial liberalization and remittances: recent panel evidence. J. Int. Trade Econ. Develop. 24, 1077-1102. doi: 10.1080/09638199.2014.1001772

Barnabe, A. Y. (2021). "Migrant remittances and financial inclusion in Africa: a dynamic and long-run approach," in Handbook of Research on Institution Development for Sustainable and Inclusive Economic Growth in Africa, (Philadelphia, PA: IGI Global), 153-168.

Baum, C. F., Schaffer, M. E., and Stillman, S. (2007). Enhanced routines for instrumental variables/generalized method of moments estimation and testing. Stata J. 7, 465-506. doi: 10.1177/1536867X0800700402

Beine, M., Lodigiani, E., and Vermeulen, R. (2012). Remittances and financial openness. Reg. Sci. Urban Econ. 42, 844-857. doi: 10.1016/j.regsciurbeco.2011.12.005

Bellantuono, N., Pontrandolfo, P., and Scozzi, B. (2021). Measuring the openness of innovation. Sustainability 13:2205. doi: 10.3390/su13042205

Bevan, A., Estrin, S., and Meyer, K. J. I., b. r. (2004). Foreign investment location and institutional development in transition. Economies 13, 43-64. doi: 10.1016/j.ibusrev.2003.05.005

Blundell, R., and Bond, S. (1998). Initial conditions and moment restrictions in dynamic panel data models. J. Econo. 87, 115-143. doi: 10.1016/S0304-4076(98)00009-8

Bolarinwa, S., and Akinbobola, T. O. (2021). Remittances-financial development nexus: causal evidence from four African countries. Ilorin J. Econ. Policy 8, 1-17.

Breusch, T. S., and Pagan, A. R. (1980). The Lagrange multiplier test and its applications to model specification in econometrics. Rev. Econ. Stud. 47, 239-253. doi: 10.2307/2297111

Broner, F., Didier, T., Erce, A., and Schmukler, S. L. (2011). Gross Capital Flows: Dynamics and Crises. Washington, DC: The World Bank.

Chami, R., Fullenkamp, C., and Jahjah, S. (2003). Are immigrant remittance flows a source of capital for development? MF Staff Pap. 52, 55-81. doi: $10.2139 /$ ssrn. 463002

Chami, R., Fullenkamp, C., and Jahjah, S. (2005). Are immigrant remittance flows a source of capital for development? IMF Staff Papers 52, 55-81. doi: $10.2307 / 30035948$

Chen, F., Jiang, G., and Kitila, G. M. (2021). Trade openness and $\mathrm{CO}_{2}$ emissions: the heterogeneous and mediating effects for the belt and road countries. Sustainability 13:1958. doi: 10.3390/su13041958

Chinn, M. D., and Ito, H. (2008). A new measure of financial openness. J. Compar. Policy Anal. 10, 309-322. doi: 10.1080/13876980802231123

Chowdhury, M. B. (2011). Remittances flow and financial development in Bangladesh. Econ. Model. 28, 2600-2608. doi: 10.1016/j.econmod.2011.07.013

Combes, J.-L., Kinda, T., Ouedraogo, R., and Plane, P. (2017). Does it pour when it rains? Capital flows and economic growth in developing countries. HAL; 2017 Feb 3.

Dastidar, S. G. (2017). Impact of remittances on economic growth in developing countries: the role of openness. Glob. Econ. J. 17:66. doi: 10.1515/gej-2016-0066

De Haas, H. (2010). Migration and development: A theoretical perspective. Int. Migr. Rev. 44, 227-264. doi: 10.1111/j.1747-7379.2009.00804.x

De, P. K., and Ratha, D. (2012). Impact of remittances on household income, asset and human capital: evidence from Sri Lanka. Migr. Develop. 1, 163-179. doi: 10.1080/21632324.2012.719348

Elbadawi, I. A., and Rocha, R. R. (1992). Determinants of Expatriate Workers' Remittances in North Africa and Europe: Country Economics Department. Washington:WC: World Bank.

Ellahi, S., and Omer, M. (2021). Do Workers' Remittances Promote Economic Growth in Pakistan? Available online at: 10.21098/jimf.v6i4.1187

Foad, H. (2010). The E ects of Wars and Financial Crises on Migration and Remittances in the Middle East. Available online at: www.ipacademy.org/Programs/Research/ProgReseSecDev_Pub.ht

Fujii, E. (2019). What does trade openness measure? Oxf. Bull. Econ. Stat. 81, 868-888. doi: $10.1111 /$ obes. 12275

Gammeltoft, P. (2002). Remittances and other financial flows to developing countries. Int. Migr. 40, 181-211. doi: 10.1111/1468-2435.00216
Giuliano, P., and Ruiz-Arranz, M. (2009). Remittances, financial development, and growth. J. Dev. Econ. 90, 144-152. doi: 10.1016/j.jdeveco.2008.10.005

Gnangnon, S. K. (2020). Trade openness and diversification of external financial flows for development: an empirical analysis. South Asian J. Macroecon. Public Finan. 9, 22-57. doi: 10.1177/2277978719898974

Gries, T., Kraft, M., and Meierrieks, D. (2009). Linkages between financial deepening, trade openness, and economic development: causality evidence from Sub-Saharan Africa. World Dev. 37, 1849-1860. doi: 10.1016/j.worlddev.2009.05.008

Hakura, M. D., Chami, M. R., and Montiel, M. P. (2009). Remittances: an automatic output stabilizer? Int. Monetary Fund. 33. doi: 10.5089/9781451872385.001

Han, C., Phillips, P. C., and Sul, D. (2014). X-differencing and dynamic panel model estimation. Econ. Theory 30, 201-251. doi: 10.1017/S0266466613000170

Hansen, L. P., and Singleton, K. J. (1982). Generalized instrumental variables estimation of nonlinear rational expectations models. Econometrica 50, 1269-1286. doi: 10.2307/1911873

Im, K. S., Pesaran, M. H., and Shin, Y. (2003). Testing for unit roots in heterogeneous panels. J. Econom. 115, 53-74. doi: 10.1016/S0304-4076(03)00092-7

Inoue, T. (2019). Financial inclusion and poverty reduction in India. J. Financ. Econ. Policy. 11, 21-33. doi: 10.1108/JFEP-01-2018-0012

Issabayev, M., Saydaliyev, H., Avsar, V., and Chin, L. (2020). Remittances, institutions and financial inclusion: new evidence of non-linearity. Glob. Econ. J. 20:2050002. doi: 10.1142/S2194565920500025

Jia, Z., Mehta, A. M., Qamruzzaman, M., and Ali, M. (2021). Economic Policy uncertainty and financial innovation: is there any affiliation? Front. Psychol. 12:1781. doi: 10.3389/fpsyg.2021.631834

Kao, C. (1999). Spurious regression and residual-based tests for cointegration in panel data. J. Econom. 90, 1-44. doi: 10.1016/S0304-4076(98) 00023-2

Kapur, D., and Singer, D. (2006). Remittances, Government Spending, and the Global Economy. Paper presented at the Annual Meeting, San Diego, CA.

Kumar, B. (2019). Remittances, poverty and welfare: Evidence from Cumilla, Bangladesh. Am. J. Data Mining Knowl. Discov. 4, 46-52. doi: 10.11648/j.ajdmkd.20190401.17

Kumar, B., Ali, S. R., and Kibria, M. G. (2021). "International remittances, household welfare, and women empowerment: evidence from Bangladesh," in Women Empowerment and Well-Being for Inclusive Economic Growth (New York, NY: IGI Global), 174-190.

Kumar, R. R. (2013). Remittances and economic growth: a study of Guyana. Econ. Syst. 37, 462-472. doi: 10.1016/j.ecosys.2013.01.001

Kumar, R. R. (2011). Nexus between financial and technology inclusion, remittances and trade openness vis-à-vis growth: a study of Nepal. Econ. J. Nepal 34, 13-30. https://www.nepjol.info/index.php/EJON/article/view/ 10118[https://www.nepjol.info/index.php/EJON/article/view/10118]

Levin, A., Lin, C.-F., and Chu, C.-S. J. (2002). Unit root tests in panel data: asymptotic and finite-sample properties. J. Econom. 108, 1-24. doi: 10.1016/S0304-4076(01)00098-7

Maddala, G. S., and Wu, S. (1999). A comparative study of unit root tests with panel data and a new simple test. Oxf. Bull. Econ. Stat. 61, 631-652. doi: 10.1111/1468-0084.0610s1631

Mundaca, B. G. (2009). Remittances, financial market development, and economic growth: the case of Latin America and the Caribbean. Rev. Develop. Econ. 13, 288-303. doi: 10.1111/j.1467-9361.2008.00487.x

Muneeb, M. A., Md, Q., Ayesha, S., and Asad, A. L. I. (2021). The role of remittances in financial development: evidence from nonlinear ARDL and Asymmetric causality. J. Asian Financ. Econ. Bus. 8, 139-154 doi: 10.13106/jafeb.2021

Nahar, F. H., Adha, M. A., and Azizurrohman, M. (2018). Effects of Remittances on Economic Growth in Indonesia. Paper presented at the 9th International Conference on Socio-economic and Environmental Issues in Development.

Nickell, S. (1981). Biases in dynamic models with fixed effects. Econ. J. Econ. Soc. 1417-1426. doi: 10.2307/1911408

Nyamongo, E. M., Misati, R. N., Kipyegon, L., and Ndirangu, L. (2012). Remittances, financial development and economic growth in Africa. J. Econ. Bus. 64, 240-260. doi: 10.1016/j.jeconbus.2012.01.001 
Omri, A., and Sassi-Tmar, A. (2015). Linking FDI inflows to economic growth in North African countries. J. Knowl. Econ. 6, 90-104. doi: $10.1007 / \mathrm{s} 13132-013-0172-5$

Pandikasala, J., Vyas, I., and Mani, N. (2021). Do financial development drive remittances? empirical evidence from India. J. Public Affairs e2269. doi: $10.1002 /$ pa.2269

Pedroni, P. (2001). Purchasing power parity tests in cointegrated panels. Rev. Econ. Stat. 83, 727-731. doi: 10.1162/003465301753237803

Pedroni, P. (2004). Panel co-integration: asymptotic and finite sample properties of pooled time series tests with an application to the PPP hypothesis. Econ. Theory 20, 597-625. doi: 10.1017/S0266466604203073

Pesaran, M. H. (2006). Estimation and inference in large heterogeneous panels with a multifactor error structure. Econometrica 74, 967-1012. doi: $10.1111 /$ j.1468-0262.2006.00692.x

Pesaran, M. H. (2007). A simple panel unit root test in the presence of cross-section dependence. J. Appl. Econom. 22, 265-312. doi: 10.1002/jae.951

Pesaran, M. H., Ullah, A., and Yamagata, T. (2008). A bias-adjusted LM test of error cross-section independence. Econom. J. 11, 105-127. doi: 10.1111/j.1368-423X.2007.00227.x

Pesaran, M. H., and Yamagata, T. (2008). Testing slope homogeneity in large panels. J. Econom. 142, 50-93. doi: 10.1016/j.jeconom.2007.05.010

Pesaran, M. H. (2004). General diagnostic tests for cross section dependence in panels. Empiric. Econ. 60, 13-50. doi: 10.1007/s00181-020-01875-7

Peth, S. A., and Sakdapolrak, P. (2020). When the origin becomes the destination: lost remittances and social resilience of return labour migrants in Thailand. Area 52, 547-557. doi: 10.1111/area.12598

Qamruzzaman, M., and Jianguo, W. (2020a). The asymmetric relationship between financial development, trade openness, foreign capital flows, and renewable energy consumption: Fresh evidence from panel NARDL investigation. Renew. Energy 159, 827-842. doi: 10.1016/j.renene.2020.06.069

Qamruzzaman, M., and Jianguo, W. (2020b). Nexus between remittance and household consumption: fresh evidence from symmetric or asymmetric investigation. J. Econ. Develop. 45, 1-27.

Raihan, S., Sugiyarto, G., Bazlul, H. K., and Jha, S. (2009). Remittances and household welfare: a case study of Bangladesh. Asian Develop. Bank Econ. Working Paper 189. doi: 10.2139/ssrn.1618142

Raihan, S., Uddin, M., and Ahmmed, S. (2021). Impact of foreign remittances on the household spending behaviour in Bangladesh. Migr. Develop. 1-23. doi: 10.1080/21632324.2020.1870835

Ratha, D., and Mohapatra, S. (2007). Increasing the Macroeconomic Impact of Remittances on Development. Washington, DC: World Bank.

Ratha, D. (2005). Workers' remittances: an important and stable source of external development finance. Develop. Impact Fut. Pros. 19-51.

Ratha, D. (2007). Leveraging remittances for development. Policy Brief 3, 1-16.

Russell, D. E. (1986). The Secret Trauma: Incest in the Lives of Girls and Women. New York, NY: Basic Books.

Sargan, J. D. (1958). The estimation of economic relationships using instrumental variables. Econom. J. Econom. Soc. 393-415. doi: 10.2307/1907619

Schiff, M., and Özden, Ç. (2005). International MIGRATION, Remittances, and the Brain Drain. Washington, DC: The World Bank.

Shabani, Z. D., and Shahnazi, R. (2019). Energy consumption, carbon dioxide emissions, information and communications technology, and gross domestic product in Iranian economic sectors: a panel causality analysis. Energy 169, 1064-1078. doi: 10.1016/j.energy.2018.11.062

Sibindi, A. B., and Bimha, A. (2014). Banking sector development and economic growth_evidence from Zimbabwe. Banks Syst 9, 51-58.
Sobiech, I. (2019). Remittances, finance and growth: does financial development foster the impact of remittances on economic growth? World Dev. 113, 44-59. doi: 10.1016/j.worlddev.2018.08.016

Solarin, S. A., and Shahbaz, M. (2015). Natural gas consumption and economic growth: the role of foreign direct investment, capital formation and trade openness in Malaysia. Renew. Sustain. Energy Rev. 42, 835-845. doi: 10.1016/j.rser.2014.10.075

Soto, M. (2009). System GMM estimation with a small sample.

Steiner, A. C., and Saadma, T. (2016). Measuring De Facto Financial Openness: A New Index.

Stojanov, R., Němec, D., and Žídek, L. (2019). Evaluation of the long-term stability and impact of remittances and development aid on sustainable economic growth in developing countries. Sustainability 11:1538. doi: $10.3390 /$ su11061538

Straubhaar, T. (1986). The determinants of workers' remittances: The case of Turkey. Weltwirtsch. Arch. 122, 728-740. doi: 10.1007/BF02707858

Udi, J., Bekun, F. V., and Adedoyin, F. F. (2020). Modeling the nexus between coal consumption, FDI inflow and economic expansion: does industrialization matter in South Africa? Environ. Sci. Pollut. Res. 1-12. doi: $10.1007 /$ s11356-020-07691-x

Westerlund, J. (2008). Panel co-integration tests of the Fisher effect. J. Appl. Econ. 23, 193-233. doi: 10.1002/jae.967

$\mathrm{Xu}$, S., Qamruzzaman, M., and Adow, A. H. (2021). Is financial innovation bestowed or a curse for economic sustainably: the mediating role of economic policy uncertainty. Sustainability 13: 2391. doi: 10.3390/su13042391

Yang, D., and Choi, H. (2007). Are remittances insurance? evidence from rainfall shocks in the Philippines. World Bank Econ. Rev. 21, 219-248. doi: 10.1093/wber/lhm003

Yasmeen, H., Tan, Q., Zameer, H., Vo, X. V., and Shahbaz, M. (2021). Discovering the relationship between natural resources, energy consumption, gross capital formation with economic growth: can lower financial openness change the curse into blessing. Resources Policy 71:102013. doi: 10.1016/j.resourpol.2021.102013

Zhunio, M. C., Vishwasrao, S., and Chiang, E. P. (2012). The influence of remittances on education and health outcomes: a cross country study. Appl. Econ. 44, 4605-4616. doi: 10.1080/00036846.2011.59 3499

Conflict of Interest: The authors declare that the research was conducted in the absence of any commercial or financial relationships that could be construed as a potential conflict of interest.

Publisher's Note: All claims expressed in this article are solely those of the authors and do not necessarily represent those of their affiliated organizations, or those of the publisher, the editors and the reviewers. Any product that may be evaluated in this article, or claim that may be made by its manufacturer, is not guaranteed or endorsed by the publisher.

Copyright (C) 2021 Miao and Qamruzzaman. This is an open-access article distributed under the terms of the Creative Commons Attribution License (CC BY). The use, distribution or reproduction in other forums is permitted, provided the original author(s) and the copyright owner(s) are credited and that the original publication in this journal is cited, in accordance with accepted academic practice. No use, distribution or reproduction is permitted which does not comply with these terms. 